に上ってもうれしいものである。 さらにグルメ時代に マッチした食品用脱水シート「ピチット」もここで開発 されたもので， 61 年日経年間最優秀製品賞を授賞し， 好評だと聞いた。

最後に化学品研究所の本館を見せていただき，管理棟 にもどる.

カラー写真のいっぱい入った会社案内を見るといかに もはなやかなふん囲気を想像しがちだが，実際は誠に地
味な，つつましやかな工場，研究所の仕事にとまどいさ え感ずるが，しかしその中に脈々と培われた技術は一朝 一夕にできたものではないことをあらためて感じ，また， 工業原料,製品の流れは一社内によどまらず多くの会社, 工場と有機的につながっており，それぞれがきわめて重 要な役割をもっていることを認識した。

最後にお忙しいところ, 企画, ご案内していただいた 工場，研究所の皆様に感謝します。

\section{登表学会に参加して 国際会语究}

\section{INTELEC 87}

INTELEC (インテレック) とは本誌の大部分の読者 によって聞きなれない名前と思うが，International Telecommunications Energy Conference の略で文 字通り通信用電源に関する国際会議である. 1978 年から 始まってアメリカとそれ以外の国で交替に，最近は毎年 開催され，本年は 6 月 14-17 日スエーデンのストック ホルムで 36 ケ国から 500 人以上を集めて行われた，電 源の会議であるから電気技術者が主導権をとり, 演題も 回路関係が多いが, 電池(太陽電池を除く) が 16 件（総 計 115 件中）含まれ，各国の電池技術者も90 名以上出 席 (登録)していた。これは通信電源としての電池の重 要性を示すものであり，事実この会議の電池の session は電池の特性が実用的な面から discussされる数少い 機会の 1 つである。電池の用途も単なる商用電源での float 使用だけでなく太陽光や風力などの自然エネル ギ一発電やディーゼル発電機の間歇運転との組合わせな
ビ多様である.

西ドイツの電池メーカーVarta 社の Dr.Kiehne は この 10 年間本会合に出された電池に関する発表のまと めを行い, 初期は概説的なものが多かったが近年は内容 に新規性のあるもの上なったこと，将来の通信用電源之 して大規模設備用には燃料電池が, また小型設備にはり チウム電池も使われるようになるう，電池はメンテナン スフリー化に向うべきこと等をのべた．またアメリカで 広く使用されている $\mathrm{Pb}-\mathrm{Ca}$ 合金格子体の鉛電池の float 使用時の電圧のバラッキが $\mathrm{Pb}-\mathrm{Sb}$ 合金のものよ り大きい原因が負極板にあり，この負極電位を一定にす るためごく少量の $\mathrm{Pt}$ を添加するという変った案 ( C\&D 社）もあった。この外にも使用中の鉛電池電極の電位 の話があり,Dr.Feder (元 Bell 研究所, 同筒型鉛電池 の設計者)がスライドで「Tafel is King」と表現して いたのは秀逸であった。

（湯浅電池 岡田和夫）

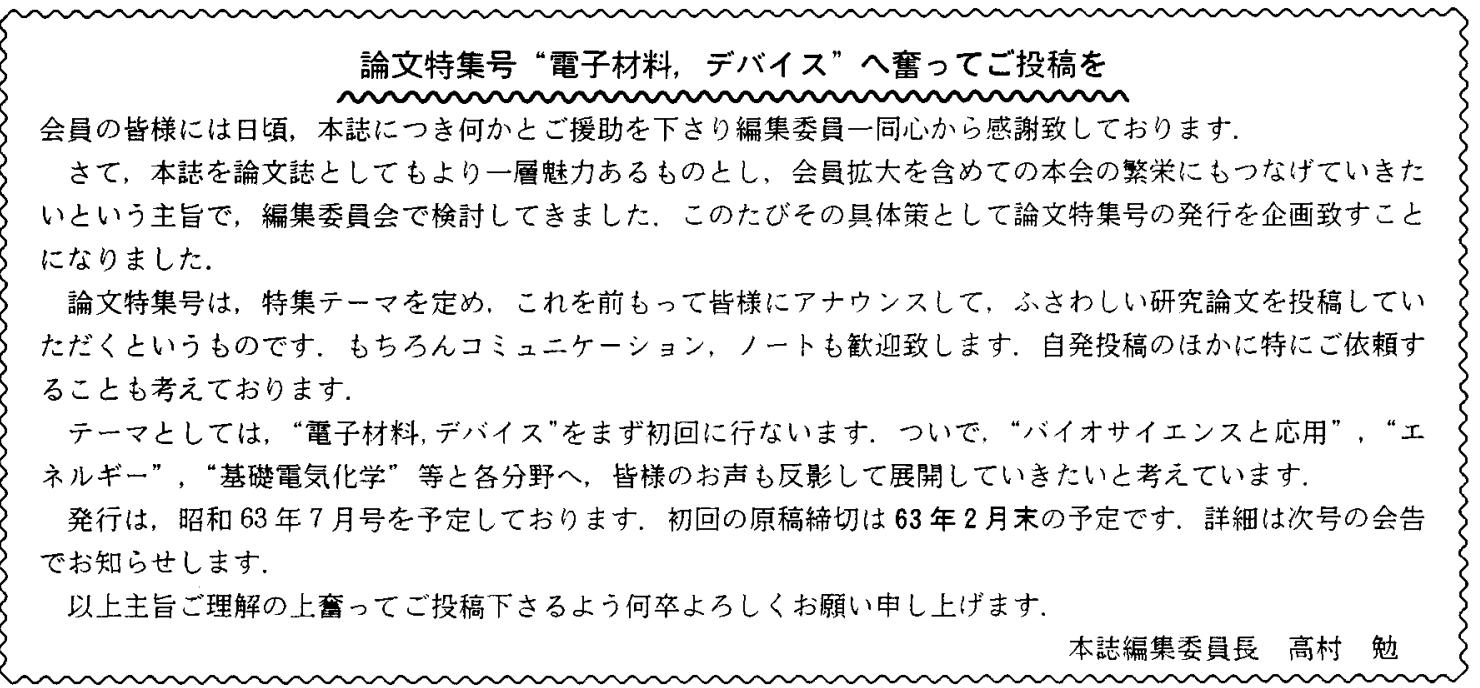

